\title{
Urgences
}

\section{Les souliers}

\section{Karine Barriault}

Numéro 12, 3e trimestre 1984

Spécial humour

URI : https://id.erudit.org/iderudit/025188ar

DOI : https://doi.org/10.7202/025188ar

Aller au sommaire du numéro

Éditeur(s)

Urgences

ISSN

0226-9554 (imprimé)

1927-3924 (numérique)

Découvrir la revue

Citer ce document

Barriault, K. (1984). Les souliers. Urgences, (12), 73-75.

https://doi.org/10.7202/025188ar

Ce document est protégé par la loi sur le droit d'auteur. L'utilisation des services d'Érudit (y compris la reproduction) est assujettie à sa politique d'utilisation que vous pouvez consulter en ligne.

https://apropos.erudit.org/fr/usagers/politique-dutilisation/
Cet article est diffusé et préservé par Érudit.

Érudit est un consortium interuniversitaire sans but lucratif composé de l'Université de Montréal, l'Université Laval et l'Université du Québec à Montréal. Il a pour mission la promotion et la valorisation de la recherche. https://www.erudit.org/fr/ 



\section{Bonjour,}

Je m'appelle Karine Barriault, j'ai 8 ans, je commence ma 3 e année. Je vous envoie 3 poèmes afin de participer à votre revue Urgences. J'aime beaucoup faire des poèmes, aussi quand c'est la fête de papa ou maman, je leur compose des poèmes dans leur carte. Pendant mes vacances j'ai composé plusieurs poèmes. Je trouve que cela compose mieux quand je suis dans ma chambre, sur mon lit et que je suis tranquille. J'aimerais que mes poèmes paraissent dans votre revue, mais si vous ne pouvez pas, répondez moi quand même.

\section{Merci}

\section{LES SOULIERS}

Nous avons des souliers,

C'est pour mieux danser.

Nous avons des souliers,

Pour descendre l'escalier.

Mon soulier est disparu.

Il est dans la rue.

Mon soulier s'appelle Toupin,

Son ami est très coquin. 


\section{LES CHATONS}

J'ai deux beaux chatons,

Ils sont bien mignons.

J'ai du bon manger,

Ils vont mieux chasser.

Ils sont drôles et coquins,

Ils travaillent au moulin.

J'aime les papillons,

Ils aiment les gros bonbons.

Je me mets des pantalons,

Ils se mettent des blousons.

\section{LA NATURE}

J'aime la nature,

Elle nous donne de la confiture.

Si elle nous envoie de la pluie,

C'est qu'elle en a envie.

Si elle nous envoie du soleil,

C'est parce qu'elle se réveille.

Si elle nous envoie de la brume

C'est parce qu'elle a le rhume. 